\title{
Catalytic properties, functional attributes and industrial applications of $\beta$-glucosidases
}

\author{
Gopal Singh $^{1}$ - A. K. Verma ${ }^{2} \cdot \operatorname{Vinod~Kumar}^{3}$
}

Received: 20 April 2015/Accepted: 19 June 2015/Published online: 31 December 2015

(C) The Author(s) 2015. This article is published with open access at Springerlink.com

\begin{abstract}
Glucosidases are diverse group of enzymes with great functional importance to biological systems. These are grouped in multiple glycoside hydrolase families based on their catalytic and sequence characteristics. Most studies carried out on $\beta$-glucosidases are focused on their industrial applications rather than their endogenous function in the target organisms. $\beta$-Glucosidases performed many functions in bacteria as they are components of large complexes called cellulosomes and are responsible for the hydrolysis of short chain oligosaccharides and cellobiose. In plants, $\beta$-glucosidases are involved in processes like formation of required intermediates for cell wall lignification, degradation of endosperm's cell wall during germination and in plant defense against biotic stresses. Mammalian $\beta$-glucosidases are thought to play roles in metabolism of glycolipids and dietary glucosides, and signaling functions. These enzymes have diverse biotechnological applications in food, surfactant, biofuel, and agricultural industries. The search for novel and improved $\beta$-glucosidase is still continued to fulfills demand of an industrially suitable enzyme. In this review, a comprehensive overview on detailed functional roles of $\beta$-glucosidases in different organisms, their industrial applications, and recent cloning and expression studies
\end{abstract}

Vinod Kumar

sangwan.vinod@yahoo.com

1 Institute of Himalayan Bioresource Technology, Palampur 176062, India

2 Department of Biochemistry, College of Basic Sciences and Humanities, G. B. Pant University of Agriculture and Technology, Pantnagar 263145, India

3 Department of Biotechnology, Akal College of Agriculture, Eternal University, Baru Sahib, Sirmour 173101, India with biochemical characterization of such enzymes is presented for the better understanding and efficient use of diverse $\beta$-glucosidases.

Keywords $\beta$-Glucosidases - Glycoside hydrolase . Cellulosome $\cdot$ Glucosides $\cdot$ Cellulase

\section{Introduction}

$\beta$-Glucosidases ( $\beta$-D-glucopyrranoside glucohydrolase) [E.C.3.2.1.21] are the enzymes which hydrolyze the glycosidic bond of a carbohydrate moiety to release nonreducing terminal glycosyl residues, glycoside and oligosaccharides (Bhatia et al. 2002; Morant et al. 2008; Cairns and Esen 2010; Li et al. 2013). These enzymes are present in all kinds of organisms including bacteria, archaea, and eukaryotes, and play several important roles such as biomass conversion in microorganisms, breakdown of glycolipids and process of lignification, involve in defense against pests, phytohormones activation, catabolism of cell wall in plants and both plant-microbes and plant-insects interaction. $\beta$-Glucosidase also plays an important role in the treatment of Gaucher's disease (resulting from a deficiency of $\beta$-glucosidase) in which accumulation of glycoceramides takes place in the lysosomal tissues (Butters 2007). $\beta$-Glucosidases are the essential part of cellulase system (cellulose metabolizing enzymes) and catalyze the last and final step in cellulose hydrolysis. Cellulase enzymes hydrolyze the cellulose to produce cellobiose and other short oligosaccharides which are finally hydrolyzed to glucose by $\beta$-glucosidase. All the enzymes, which are involved in cellulose hydrolysis, are normally grouped as cellulase system (Fig. 1). It consists of the following enzymes: endoglucanase (endo-1, $4-\beta$ - 


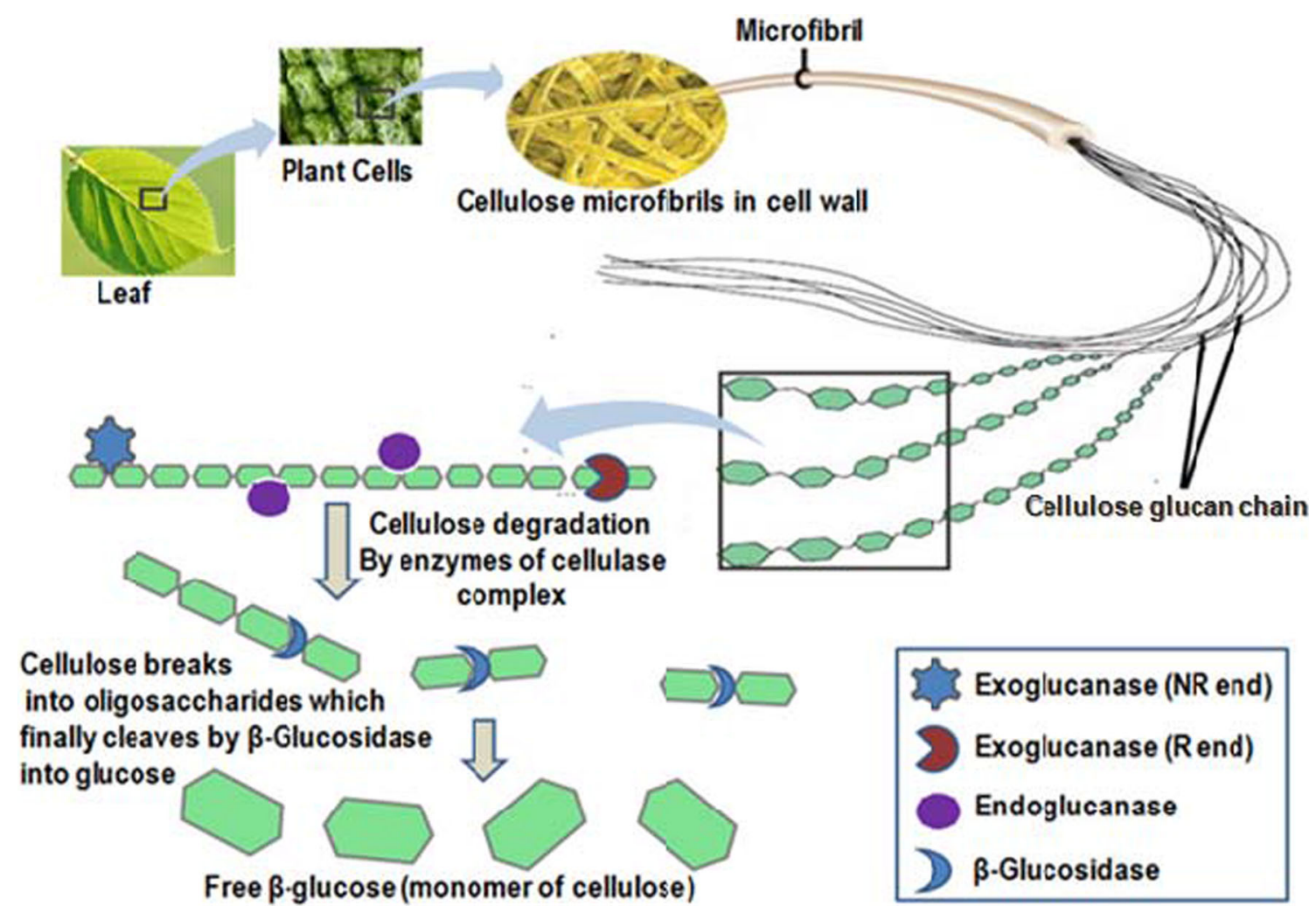

Fig. 1 Diagrammatic overview of cellulose metabolism by cellulase system: during cellulose hydrolysis, cellulase along with exo and endoglucanase acts on the cellulosic fibers and hydrolyzed it into the smaller sized oligosaccharides. These smaller molecules are finally utilized by $\beta$-glucosidase as a substrate to release glucose as the final product of complete hydrolysis of cellulosic substance glucanase [E.C.3.2.1.4]), exoglucanase (cellobiohydrolase) (exo-1, 4- $\beta$-glucanase [E.C.3.2.1.91]) and $\beta$-glucosidase ( $\beta$-D-glucoside glycohydrolase [E.C.3.2.1.21]) (Teeri 1997). The endoglucanase randomly hydrolyzes the $\beta-1-4$ bonds in the middle portion of cellulose molecule and the exoglucanase acts at reducing and non-reducing ends to release the cellobiose and other oligosaccharides. Finally, these oligosaccharides are converted to glucose by $\beta$-glucosidase (Bhat and Bhat 1997).

$\beta$-Glucosidases are widely used in the various biotechnological processes, including the production of biofuel and ethanol from cellulosic agricultural wastes and synthesis of useful $\beta$-glucosides ( $\mathrm{Li}$ et al. 2013). These enzymes are employed in industry for hydrolysis of bitter compounds during juice extraction and liberation of aroma from wine grapes (Gueguen et al. 1998; Harhangi et al. 2002). In flavor industry, $\beta$-glucosidases are the key enzymes in the enzymatic release of aromatic compounds from glucosidic precursors present in fruits and fermenting products (Krisch et al. 2010). Also, this has large potential for application in food processing industries and used as a flavor enzyme to enhance the flavor of wine, tea and fruit juice (Keerti et al. 2014). $\beta$-Glucosidases play an important role in flavor liberation from glucosylated ( $\beta$-glucosides conjugated) precursors in fruits and other plant tissues (Krisch et al. 2010). Cleavage of phenolic and phytoestrogen glucosides from fruits and vegetables is also carried out by applying this enzyme to extract medicinally important compounds and to enhance the quality of beverages (Schroder et al. 2014). $\beta$-Glucosidases hydrolyzed anthocyanine products, i.e., anthocyanidins and sugar aglycones are less soluble than anthocyanines, possess little colour, tend to precipitate and can be removed more easily. $\beta$-Glucosidases can improve the organoleptic properties of citrus fruits and juices in which bitterness is in part due to a glucosidic compound, naringin whose hydrolysis requires in succession, an $\alpha$-rhamnosidase and a $\beta$-glucosidase (Riou et al. 1998). $\beta$-Glucosidases have been the subject of recent research due to the key role of these enzymes in biological processes and for many biotechnological applications. In present review, we briefly explain the generalized action mechanisms of $\beta$-glucosidase enzymes, their functional role in different types of organisms and significant contribution in different industries along with a brief look on the current research for improving the efficiency of this industrially important enzyme. 


\section{Types of $\beta$-glucosidases and their classification}

$\beta$-Glucosidases are common among plants, fungi and bacteria, and showed an identical similarity with respect to their sequences and structures. They can be classified on the basis of their substrate activity or their nucleotide sequence identity. Based on substrate specificity, $\beta$-glucosidases are grouped into three classes: (i) aryl- $\beta$-D-glucosidases (having strong affinity for aryl- $\beta$-D-glucosides), (ii) cellobiases (hydrolyze only disaccharides) and (iii) broad specificity glucosidases (exhibit activity on many substrate types and are the most commonly found $\beta$-glucosidases) (Rajan et al. 2004). On the basis of sequence homology, $\beta$-glucosidases have been divided into two subfamilies (i) BGA ( $\beta$-glucosidases and phospho- $\beta$-glucosidases from bacteria to mammals) and (ii) BGB ( $\beta$-glucosidases from yeasts, molds and rumen bacteria) (Cantarel et al. 2009; Krisch et al. 2010). An alternative classification system for glycoside hydrolases based on amino acid sequence and structural similarity has also been developed (Henrissat and Davies 1997). In this system, those enzymes with overall amino acid sequence similarity and wellconserved sequence motifs are considered in a single family. At present, 133 glycoside hydrolase $(\mathrm{GH})$ families are listed in the frequently updated Carbohydrate Active enZYme (CAZY) website (http://www.cazy.org) (Cantarel et al. 2009; Cairns and Esen 2010). These families are further classified into clans. The families with similar catalytic domain structures and conserved catalytic amino acids, suggestive of a common ancestry and catalytic mechanism, are grouped under the same clan. Clan GH-A contains largest number of families including $\beta$-glucosidase containing families GH1, GH5 and GH30. Largest number of characterized $\beta$-glucosidases belongs to GH1 family. Family GH1 includes $\beta$-glucosidases from archaebacteria, plants and mammals, and family GH3 comprises $\beta$-glucosidases of some bacterial, mold and yeast origin (Cairns and Esen 2010; Krisch et al. 2010).

International Union of Biochemistry and Molecular Biology (IUBMB) classified GH families into the structurally determined families (Henrissat and Davies 1997; Harris et al. 2010). This family classification based on the structural features of the enzymes is more informative than substrate specificity because the complete range of substrates is very difficult to determine for individual enzymes. The structural features of a family can be used to study the structures of other members of the same family by applying some bioinformatics tools and system biology approach. Tertiary structure, particularly at the active site, dictates the enzyme mechanism and their substrate specificity. The family classification also explains the evolution of the glycoside hydrolases (Lynd et al. 2002). A classical $(\beta / \alpha)_{8}$ barrel Folds as a key feature of GH1 family $\beta$-glucosidase was reported in X-ray crystallographic structure of $\beta$-glucosidase BGL1A from a basidiomycete (Phanerochaete chrysosporium) by Nijikken et al. (2007). Structure of human cytosolic $\beta$-glucosidase was also illustrated by $\mathrm{X}$-ray crystallography and reported the existence of the same $(\beta / \alpha)_{8}$ barrel (Tribolo et al. 2007).

\section{Catalytic mechanism of $\beta$-glucosidases}

For elucidating the catalytic mechanism of the enzyme and the active site topology, several techniques such as $\mathrm{pH}$ dependence, inhibition, isotopic effect, and structure-reactivity studies (Kempton and Withers 1992), essential amino acid labeling with fluorosugars (Withers et al. 1992), reactions with deoxy substrate analogues (Street et al. 1992), and site-directed mutagenesis (Wang et al. 1995) have been used. $\beta$-Glucosidases cleave $\beta$-glycosidic bonds between two or more carbohydrates, or between a carbohydrate and a non-carbohydrate moiety (http://www.cazy. org/Glycoside-Hydrolases.html). Most $\beta$-glucosidases that have been characterized (i.e., GH1, GH3 and GH30 family enzymes) are retaining enzymes, and they perform catalysis in two steps, glycosylation and deglycosylation. Their catalytic mechanism is described diagrammatically in Fig. 2. Glutamate is the key active site residue and conserved among all reported $\beta$-glucosidases (Davies and Henrissat 1995; Wang et al. 1995). Two glutamate residues performed the overall catalytic reaction of $\beta$-glucosidase and one of them acts as a nucleophile (conserved as ' $\mathrm{I} /$ VTENG' motif) and the second residue works as a general acid/base catalyst (conserved as a 'TFNEP' motif) (Davies and Henrissat 1995). In the initial (glycosylation) step, glutamate, which acts as nucleophile, undergoes a nucleophilic attack on the anomeric carbon and results in a glucose-enzyme intermediate product. In the second (deglycosylation) step, a water molecule, which is activated by acid/base catalyst glutamate residue, acts as a nucleophile and breaks the glycosidic bond to release glucose (Litzinger et al. 2010). The formation of the covalent intermediate was first demonstrated with the GH1 $\beta$-glucosidase from Agrobacterium sp. by covalent labeling with 2, 4-dinitrophenyl-2-deoxy-2-fluoroglucoside (Withers et al. 1987, 1990). Tribolo et al. (2007) have reported X-ray crystallographic structure of human cytosolic $\beta$ glucosidase with the pocket shaped active site containing two glutamate residues and formed by large surface loops, surrounding the $\mathrm{C}$ termini of the barrel of $\beta$-strands. Out of two catalytic glutamate residues, the acid/base catalyzing residue was located on strand 4 while the nucleophilic residue was located on strand 7 . 


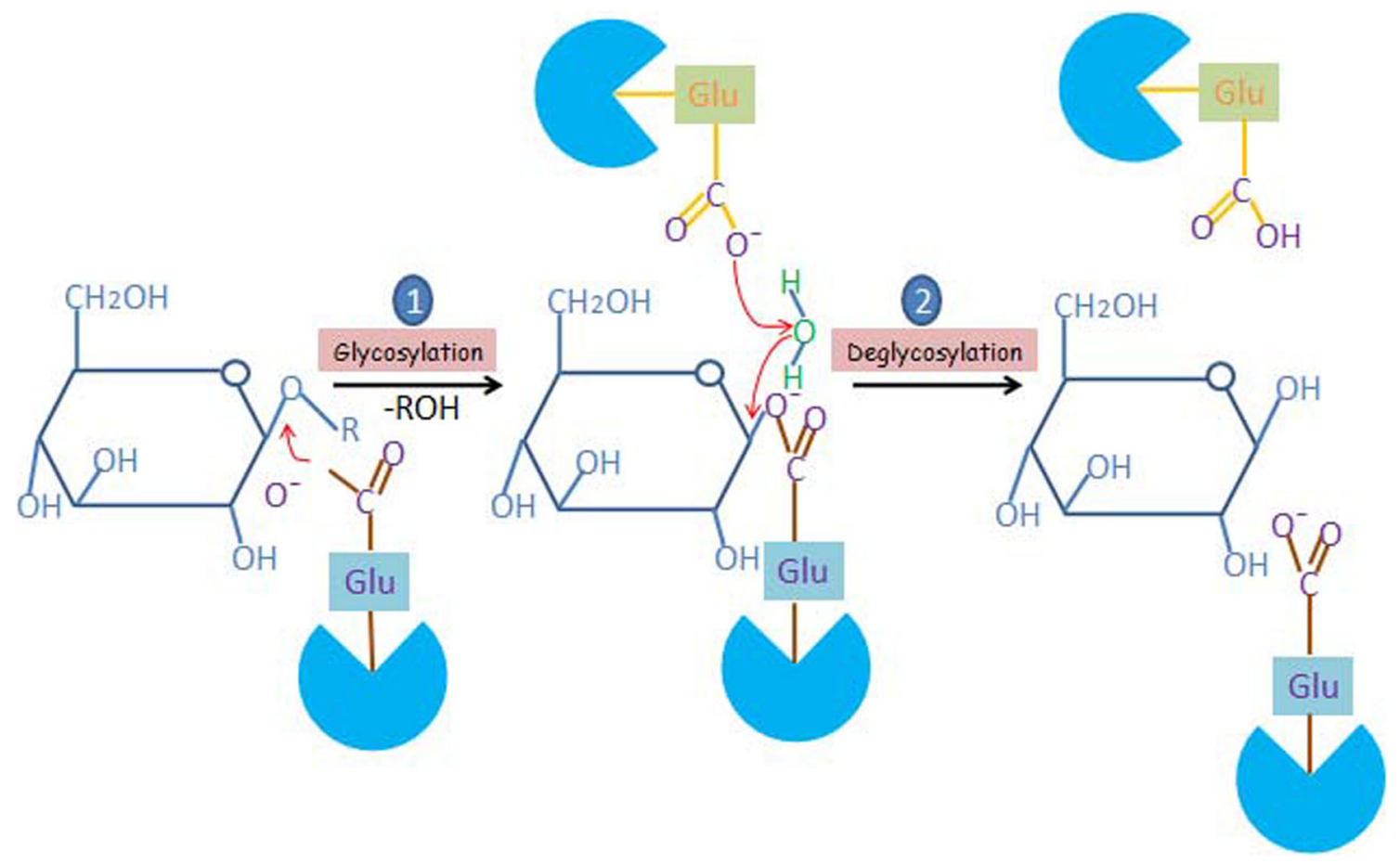

Fig. 2 Proposed "retaining" mechanism for hydrolysis of $\beta$-glycosidic bond by $\beta$-glucosidase: (1) during first glycosylation step, a conserved glutamate residue acts as nucleophile and attacks on the glycosidic bonds or cellobiose and other oligosaccharides formed by the hydrolytic action of other enzyme of cellulase system. This results into the formation of an enzyme-substrate intermediate complex, (2)

$\beta$-Glucosidases from GH9 family use an inverting mechanism, in which an activated water molecule makes a direct nucleophilic attack on the anomeric carbon to displace the aglycone in a single step (Qi et al. 2008). The catalytic base extracts a proton from the incoming water molecule while the catalytic acid protonates the leaving group aglycone.

\section{Functional roles of $\beta$-glucosidases in different organisms}

Enzymes are the biocatalysts and involved in almost all biological processes. $\beta$-Glucosidases are kind of enzymes which regulate both synthesis as well as breakdown process and involved in many essential bioconversions in all kinds of life forms. The roles of $\beta$-glucosidases in different organisms are discussed briefly in following sections.

\section{In microorganisms}

Microorganisms are one of the simplest and primitive life systems evolved in our planet. Many studies have been carried out on microorganisms with respect to $\beta$-glucosidases but most of them are focused on their industrial during second step called deglycosylation, an another conserved glutamate residue activates a water molecule present in the proximity by general acid/base catalyst reaction and now this activated water molecule acts on the intermediate complex to release the free glucose residue

application rather than their endogenous function in the target microorganisms. $\beta$-Glucosidases are reported in all forms of microorganisms such as bacteria (Isorna et al. 2007; Chen et al. 2010a; Verma et al. 2013), archea (Park et al. 2007; Cobucci-Ponzano et al. 2010; Li et al. 2013; Schroder et al. 2014) and fungi (Krisch et al. 2010; Sorensen et al. 2013). Archaea are considered as best source for industrially suitable enzymes due to their functional stability in higher temperature which is useful for their utilization in industrial operations ( $\mathrm{Li}$ et al. 2013). These enzymes play important roles in some fundamental biological processes such as in degradation of cellulose and other carbohydrates for nutrient up-take, cell wall mechanism, host-pathogen, and symbiotic association. $\beta$-Glucosidases enable phytopathogenic fungi to colonize their host plant tissues by hydrolyzing toxic glucosides to less toxic or less soluble aglycone (Collins et al. 2007). Bacterial $\beta$-glucosidases are components of large complexes called cellulosomes, contain polysaccharide degrading endoglucanases and carbohydrate binding proteins to localize the complex and to the cellulose surface and the cell membrane. In bacteria and fungi, $\beta$-glucosidases are mainly a part of the cellulase enzyme system and are responsible for the hydrolysis of short chain oligosaccharides and cellobiose (resulting from the synergistic action 
of endoglucanases and cellobiohydrolases) into glucose in a rate-limiting step (Isorna et al. 2007). It was found that the enzyme activity of cellulose-degrading enzymes decreases as the glucose chain length increases (Bhatia et al. 2002).

The principal role of $\beta$-glucosidase in cellulolytic microorganisms is to catalyze the hydrolysis of cellobiose and cello-oligosaccharides, producing glucose during bioconversion. These soluble substrates of $\beta$-glucosidase are produced from insoluble cellulose by the action of other members of the cellulose system of enzymes (Doi and Kosugi 2004). $\beta$-Glucosidase is a useful enzyme from soil microbes and contributes in maintenances of soil quality because of its central role in soil organic matter cycling (Turner et al. 2002). They are also involved in hostpathogen and symbiotic relationships as they catalyze the breaking through plant cell walls to establish pathogenic or symbiotic relationships (Gilbert et al. 2008).

\section{In plants}

In plants, $\beta$-glucosidases performed many functions. Morant et al. (2008) explain the involvement of $\beta$-glucosidases in plant metabolisms. These are involved in many key processes such as formation of required intermediates for cell wall lignification (Escamilla-Trevino et al. 2006), degradation of endosperm's cell wall during germination (Leah et al. 1995), in indole alkaloid biosynthesis (Barleben et al. 2005) activation of plant hormones (Lee et al. 2006; Verma et al. 2011), Cyanogenesis (release of toxic cyanide) (Zagrobelny et al. 2004) and in plant defense against biotic stresses (Jones et al. 2000). Plants contain defense glycosides in non-active form which are activated by the action of $\beta$-glucosidase enzymes and released as toxic compounds (Jones and Vogt 2001; Knudsen 2014). In general, the defense glycosides are stored in a different cell or a different cellular compartment from the $\beta$-glucosidases that hydrolyze them to release toxic compounds. The defense compounds tend to be stored in the vacuole, while their corresponding $\beta$-glucosidases are often found in the apoplast or plastid (Zagrobelny et al. 2008). Verdoucq et al. (2004) studied a plant $\beta$-glucosidase which plays important role in plant defense against pests. These enzymes cleave specific $\beta$ glucosides to release toxic aglycone moieties. In Lotus japonicas, $\beta$-glucosidase catalyzes the bioactivation of hydroxynitrile glucosides which provide the strength against herbivores and pathogens (Morant et al. 2008; Knudsen 2014). The family $1 \beta$-glucosidase enzyme of Sorghum biocolor (Dhr1) has shown a strict specificity for its natural substrate dhurrin. While, maize $\beta$-glucosidase (Glu1), which shares $70 \%$ sequence identity with Dhr1, hydrolase a broad spectrum of substrate in addition to its natural substrate 2-O- $\beta$-glucopyranosyl-4-hydroxy-7methoxy-1,4-benzoxaxin-3-one. Sherameti et al. (2008) observed that $\beta$-glucosidase-mediated defenses are also required for endophytic fungi to develop symbiotic relationships with plants, evidently by modulating the growth of these microorganisms. $\beta$-Glucosidases appear to play roles in both the degradation of oligosaccharides presented in cell wall and release of monolignols from their glycosides to allow lignification to stabilize secondary cell walls (Kuntothom et al. 2009). These enzymes also play essential roles in plant's secondary metabolisms. The monoterpene alkaloid intermediate is hydrolyzed by a specific $\beta$-glucosidase to allow metabolism to various monoterpene alkaloids, depending on the plant (Barleben et al. 2007). $\beta$ Glucosidases could play metabolic roles to release glucosyl blocking groups from metabolic intermediates and allow metabolism to various natural products, many of which are of medicinal importance (Nomura et al. 2008).

\section{In mammals}

Mammals contain several $\beta$-glucosidases, including the family GH1 lactase-phloridzin hydrolase and cytoplasmic $\beta$-glucosidase, the GH30 human acid $\beta$-glucosidase (GBA1) and the bile acid $\beta$-glucosidase or GBA2. These enzymes are thought to play roles in metabolism of glycolipids and dietary glucosides. In addition, a group of related family $\mathrm{GH} 1$ proteins is thought to play signaling functions. Currently, five GH1 proteins are known in humans: lactase-phloridzin hydrolase (LPH), cytoplasmic $\beta$-glucosidase, Klotho ( $\alpha$-Klotho, KL) $\beta$-Klotho $(\beta-\mathrm{KL})$, and Klotho-LPH-related protein (KLPH). LPH, an intestinal hydrolase involved in food digestion, has both $\beta$-glucosidase activity toward exogenous glucosides, such as phloridzin, and $\beta$-galactosidase activity toward lactose (Arribas et al. 2000). Perhaps the best-studied mammalian $\beta$-glucosidase is the human acid $\beta$-glucosidase, which is generally considered a glucosyl ceramidase. Defects in the function of this enzyme and its transport to the lysosome lead to Gaucher's disease, in which glycoceramides accumulate in the lysosomes of tissue leukocytes leading to their swelling (Butters 2007). Mammalian cytosolic $\beta$ glucosidase from liver cells also has ability to hydrolyze many common dietary xenobiotics, including glycosides of phytoestrogens, flavonoids, simple phenolics and cyanogens, and prevents from their hazardous effect (Hays et al. 1998; Berrin et al. 2002). Such kind of cytosolic $\beta$-glucosidase was also reported from small intestine, spleen and kidney (Berrin et al. 2002). Takagi et al. (1999) reported a $\beta$-glucocerebrosidase, a kind of $\beta$-glucosidase in mammalian stratum corneum which has a role in lipid distribution during membrane structural maturation and epidermal homeostasis. 


\section{In insects and other animals}

The insect $\beta$-glucosidase has both merits and demerits: these are the main enzymes used for converting woodcellulose to glucose for biofuel production and can also be an important part of the mechanism which leads to serious damage to wood structures, landscaping trees and many agricultural crops (Zhang et al. 2012). Due to these twofold implications, $\beta$-glucosidase from insect origin is a concern of several ongoing studies to enhance the cellulose degradation and development of cellulase-specific inhibitors as termiticides for insect and pest control (Yapi et al. 2009). For these purposes, a lot of insects such as silkworm (Bombyx mori) (Byeon et al. 2005), Reticulitermes flaviceps (Xue et al. 2008), palm weevil (Rhynchophorus palmarum) (Yapi et al. 2009), termite (Reticulitermes santonensis) (Matteotti et al. 2011), cockroach (Periplaneta americana) (Koffi et al. 2012), red palm weevil (Rhynchophorus ferrugineus) (Riseh et al. 2012) and higher termites (Bujang et al. 2014) have been studied for the isolation and characterization of an efficient $\beta$ glucosidase.

Drosophila melanogaster genome contains only one GH1 gene, suggesting that insects may not synthesize this gene family at an early stage, other insects have adapted glycosides and glycoside hydrolases from the plants on which they feed for protection and digestive purposes. These genes have since evolved to provide help for the unique needs of the herbivorous insects in their battle with plant defenses to utilize the plant nutrients. A few digestive $\beta$-glycosidases from GH1 have been isolated from insect larvae that feed on plant. The larval $\beta$-glycosidases can hydrolyze gluco-oligosaccharides and plant glycosides, such as cellobiose, gentiobiose and amygdalin (Marana et al. 2001). $\beta$-Glucosidase was also reported in the gut contents of the snail (Achatina achatina) (Umezurike 1976).

\section{Isolation, cloning and expression studies for production of efficient and novel $\beta$-glucosidase}

To obtain an improved enzyme, researchers have adopted several approaches like heterogeneous expression of $\beta$ glucosidase genes from different sources (Byeon et al. 2005; Chan et al. 2011; Aftab et al. 2012), characterization of immobilized enzyme in several agents (Keerti et al. 2014) and side-directed mutagenesis to enhance the efficacy of enzymes (Wang et al. 1995; Liu et al. 2011; Agrawal et al. 2012). Cloning and expression in suitable host for bulk production of $\beta$-glucosidase enzyme is one of the primitive concerns about ongoing research on $\beta$ glucosidase. Cloned enzyme also exhibits some advantages such as showing high isoflavone glucoside-hydrolyzing activity (Kuo and Lee 2007), more resistant to glucose inhibition (Jabbour et al. 2012), and more efficient for solid state fermentation (Krisch et al. 2010). Several $\beta$-glucosidases have been cloned from bacteria, yeast, fungi, plant and animal sources with the intent of producing this enzyme on a large scale for various biotechnological applications (Collins et al. 2007; Chang et al. 2011; Aftab et al. 2012). For expression of $\beta$-glucosidase, different kind of host organisms including Pichia pastoris, Trichoderma reesei and E. coli species were used (Harhangi et al. 2002; Murray et al. 2004; Chang et al. 2011). For $\beta$-glucosidase gene cloning studies, following three strategies have been used: first, formation of a genomic DNA library followed by selection of the clones by screening for $\beta$-glucosidase production; Second, starting with a cDNA library (or a genomic library), screening of recombinant clones by specific nucleotide probes designed from a knowledge of the polypeptide sequence; and third strategy is primer designing of existing gene sequence and PCR based cloning of gene (Bhatia et al. 2002). A detailed account of properties of heterogeneously expressed $\beta$-glucosidases from various bacteria, fungi, yeasts, and plant sources is given in Table 1.

\section{Industrial application of $\beta$-glucosidases}

$\beta$-Glucosidases have both cleavage and synthesis activity of glycosidic bonds and thus involved in many crucial biological pathways such as cellular signaling, biosynthesis and degradation of structural and storage polysaccharides, host-pathogen interactions, as well as in a number of biotechnological applications. Recently, the increased demand of energy has strongly stimulated the research on the conversion of lignocellulosic biomass into reducing sugars for the subsequent ethanol production. $\beta$-Glucosidases have been the focus because of their important roles in a variety of fundamental biological processes and the synthesis of useful $\beta$-glucosides. Although the $\beta$-glucosidases of different sources have been investigated, the amounts of $\beta$-glucosidases are insufficient for effective conversion of cellulose.

The cellulolytic fungal $\beta$-glucosidases have also been the subject of numerous investigations by various research groups (Murray et al. 2004; Liu et al. 2012a). The fungal enzymes are used in several biotechnological processes, including development of novel carbohydrate foods, alcohol-based fuels and other commercial products from cellulose (Krisch et al. 2010). Liu et al. (2012a) isolated a thermostable native $\beta$-glucosidase from the lignocellulosedecomposing fungus Aspergillus fumigatus Z5. Furthermore, when it was added to lignocellulosic materials, the 


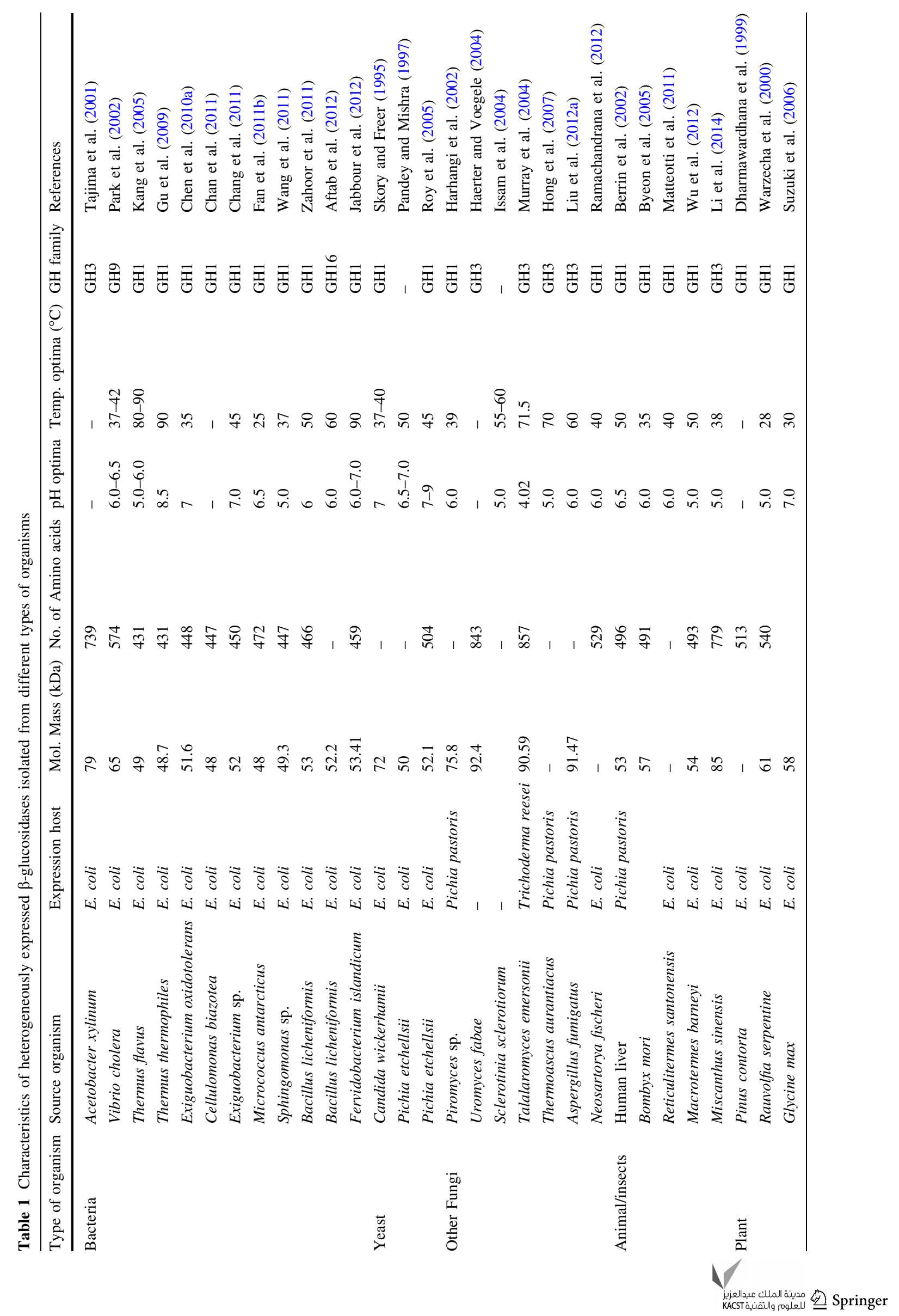


release of phenolic compounds increased, indicating that cellulose-degrading enzymes may also be involved in the breakdown of polymeric phenolic compounds.

\section{$\beta$-Glucosidase in ethanol and biofuel production}

The increased energy consumption demand and the depletion of fossil resources have laid the foundation for a shift towards sustainable production of biofuels (Sorensen et al. 2013). The use of plant biomass in the form of dedicated energy crops or cellulosic agricultural waste as an abundant and inexpensive material for biofuel is one of the current focus of industrial as well as research aspect. Most bioconversion is focused on the production of a sugar platform of simple sugars which can then biologically or chemically be converted into fuels (e.g., ethanol, butanol and hydrocarbons) (Cherubini 2010). Recently, Li et al. (2014) cloned and characterized a $\beta$-glucosidase from rumen microbes of cattle feeding with Miscanthus sinensis and this plant is used as an ideal source of biofuel. Coating of $\beta$-glucosidase on polymer nanofibers was also found more efficient for cellulosic ethanol production (Lee et al. 2010). $\beta$-Glucosidases as part of the cellulase enzyme complex hydrolyze cellobiose and cello-oligosaccharides to yield glucose which is fermentable by yeasts into fuel ethanol. Ethanol production from cellulose is performed via the degradation of cellulose to cello-oligosaccharides and glucose, followed by the conversion of glucose to ethanol by microorganisms (Kotaka et al. 2008). The cellulose is degraded by endoglucanases and exoglucanases, producing cellobiose and some cello-oligosaccharides, which can be converted to glucose by $\beta$-glucosidase. The reaction catalyzed by $\beta$-glucosidase is the most important step in the degradation of cellulose because it limits the efficiency of hydrolysis and could relieve the cellobiosemediated inhibition of exoglucanase and endoglucanase (Zhenming et al. 2009). Liu et al. (2012b) reported a yeast strain Clavispora NRRL Y-50464 that is able to utilize cellobiose as sole source of carbon and produce $\beta$-glucosidase enzyme activity for cellulosic ethanol production. It was also observed that this yeast was tolerant to the major inhibitors derived from lignocellulosic biomass pretreatment such as 2-furaldehyde (furfural) and 5-(hydroxymethyl)-2-furaldehyde (HMF), and converted furfural into furan methanol in less than $12 \mathrm{~h}$ and HMF into furan-2,5dimethanol within $24 \mathrm{~h}$ in the presence of $15 \mathrm{mM}$ each of furfural and HMF. The ethanol production of $23 \mathrm{~g} / \mathrm{l}$ was obtained without addition of exogenous $\beta$-glucosidase by this strain. However, the most widely used cellulase from Trichoderma viridae has a poor $\beta$-glucosidase activity and the accumulation of cellobiose will lead to product inhibition. Addition of thermo-tolerant $\beta$-glucosidases to commercial cellulase enzyme preparations resulted in synergistic effect and increased reducing sugar concentration (Krisch et al. 2010).

Ethanol producing bacteria have attracted much attention because their growth rate is higher than that of the Saccharomyces cerevisiae which is normally used for commercial production of fuel alcohol and to make industrial ethanol production more economical. Yanase et al. (2005) carried out his research work on Zymomonas mobilis, an ethanol producing bacterium. It has been observed that Zymomonas mobilis showed high growth rate and high specific ethanol production, which makes it an attractive candidate for industrial ethanol production, but its narrow spectrum of fermentable carbohydrates reduced its use for fuel ethanol production. To overcome from this limitation, genetic manipulation in $\beta$-glucosidase gene was used to expand the range of its carbohydrate substrates which lead to production of $0.49 \mathrm{~g}$ ethanol/g cellobiose by recombinant strain. Some of the recent studies focused on the use of microbial $\beta$-glucosidase for biofuel production from cellulosic waste are listed in Table 2 .

\section{$\beta$-Glucosidase in wine making, tea and other beverages}

In wine making, $\beta$-glucosidases play a key role in the enzymatic release of aromatic compounds from glycosidic precursors present in fruit juices, musts and fermenting products for wine making (Sestelo et al. 2004; Keerti et al. 2014), tea (Su et al. 2010) and fruit juice (Fan et al. 2011a). The natural process by endogenous plant $\beta$-glucosidases is very time consuming. Supplementation with efficient external enzymes may enhance aroma release (Gueguen et al. 1998). Monoterpenols in grapes (e.g., linalol, geraniol, nerol, citronclol, $\alpha$-terpineol and Iinalol oxide) are linked to diglucosides, which contribute to the flavor of wine (Gunata et al. 1994). The enzymatic hydrolysis of these compounds requires a sequential reaction, which produce monoglucosides. Subsequently, monoglucosides are hydrolyzed by the action of $\beta$-glucosidases. The addition of glucose-tolerant exogenous $\beta$-glucosidase isolated from fungi (e.g., A. oryzae) was shown to improve the hydrolysis of glucoconjugated aromatic compounds and enhance wine quality (Riou et al. 1998). Sestelo et al. (2004) isolated and characterized $\beta$-glucosidase from wine strain of Lactobacillus plantarum which also performs the lactic acid fermentation and culminated need of applying additional enzymes to release flavorous compounds. Recently, Gonzalez-Pombo et al. (2011) isolated and characterized an extracellular $\beta$-glucosidase from $I s$ satchenkia terricola to study the efficiency of immobilized enzyme to enhance the aroma flavor of white Muscat wine. In tea beverage industries, use of $\beta$-glucosidase enhances the content of essential oils (Krisch et al. 2010). In one 
Table 2 Recent studies on the isolation, cloning and characterization of $\beta$-glucosidase for ethanol production from cellulosic materials

\begin{tabular}{|c|c|c|c|}
\hline Microorganism type & Name of organisms & Total ethanol production & References \\
\hline \multirow[t]{5}{*}{ Bacteria } & Exiguobacterium oxidotolerans & - & Chen et al. (2010a) \\
\hline & Penicillium decumbens & - & Chen et al. (2010b) \\
\hline & Cellulomonas biazotea & - & Chan et al. (2011) \\
\hline & Clostridium phytofermentas & $25 \mathrm{mM}$ & Tolonen et al. (2011) \\
\hline & Clostridium thermocellum & $1.80 \mathrm{~g} / 1$ & Kim et al. (2013) \\
\hline \multirow[t]{6}{*}{ Yeast } & Saccharomycopsis fibuligera & $9.15 \mathrm{~g} / 1$ & Jeon et al. (2009a) \\
\hline & Saccharomycopsis fibuligera & - & Jeon et al. (2009b) \\
\hline & Issatchenkia orientalis & $29 \mathrm{~g} / \mathrm{l}$ & Kitagawa et al. (2010) \\
\hline & Saccharomyces cerevisiae & $45 \mathrm{~g} / \mathrm{l}$ & Ha et al. (2011) \\
\hline & Clavispora NRRL Y-50464 & $23 \mathrm{~g} / 1$ & Liu et al. (2012b) \\
\hline & Saccharomyces cerevisiae & $8.5 \mathrm{~g} / 1$ & Tang et al. (2013) \\
\hline \multirow[t]{10}{*}{ Other Fungi } & Aspergillus oryzae & $21.6 \mathrm{~g} / 1$ & Kotaka et al. (2008) \\
\hline & Aspergillus niger and Trichoderma reesei & - & Chauve et al. (2010) \\
\hline & Penicillium decumbens & - & Ma et al. (2011) \\
\hline & Agaricus arvensis & - & Singh et al. (2011) \\
\hline & Neocallimastix patriciarum & - & Chen et al. (2012) \\
\hline & Periconia sp. & - & Dashtban and Qin (2012) \\
\hline & Penicillium simplicissimum $\mathrm{H}-11$ & - & Bai et al. (2013) \\
\hline & White rot fungi & - & Mfombep et al. (2013) \\
\hline & Acremonium thermophilum and Thermoascus aurantiacus & - & Teugjas and Valjamae (2013) \\
\hline & $\begin{array}{l}\text { Aspergillus nidulans, Aspergillus fumigatus, and } \\
\text { Neurospora crassa }\end{array}$ & - & Bauer et al. (2006) \\
\hline
\end{tabular}

report, Su et al. (2010) used an immobilized $\beta$-glucosidase to increase the essential oil content from 6.79 to $20.69 \%$. In citrus fruit juices, the hydrolysis of naringenin by $\beta$ glucosidase found to be reducing the bitterness of the juices (Fan et al. 2011a).

\section{$\beta$-Glucosidase in soy-based foods}

Soyabean is a part of many foods and drink products and soy contains many glucosidic isoflavones like daidzin, genistin and glycitin. However, in soy-based foods the isoflavones are mainly in the inactive form of glycosides which can be hydrolyzed by applying additional $\beta$-glucosidase enzyme to convert them into aglycones (daidzein, genistein and glycitein) (Hati et al. 2015). Aglycone forms of isoflavones exhibit higher biological activity than their glucosidic forms and also absorbed faster in higher amounts during digestion (Izumi et al. 2000). Isoflavones found in soybean exhibit phytoestrogenic properties and are useful in treatment and prevention of various diseases such as cardiovascular disease and osteoporosis (Rimbach et al. 2008), prostate cancer and breast cancer (Liggins et al. 2000), relieve in menopause symptoms (Levis et al. 2010), estrogenic and antioxidant activity (Liu et al. 2010). In soy milk, the aglycon content was increased significantly either by treatment with $\beta$-glucosidase or by fermentation with a $\beta$-glucosidase producing Lactobacillus strain (Marazza et al. 2009). In the food industry, the application of gellan, an exopolysaccharide produced by Sphingomonas paucimobilis, is very limited because of its high viscosity and low solubility. Therefore, hydrolytic activity of $\beta$-glucosidases may be useful in the production of lowviscosity gellan foods. $\beta$-Glucosidases are also associated with removal of bitterness from citrus fruit juices (Roitner et al. 1984).

\section{$\beta$-Glucosidase in flavor industry}

$\beta$-Glucosidases are widely used in the flavor improvement industry. Many hundreds of different $\beta$-glucosidic flavor precursors found in plants, and their hydrolysis by $\beta$-glucosidases enhance the quality of the beverages and foods produced from them. $\beta$-Glucosidases are key enzymes in the release of aromatic compounds from glucosidic precursors present in fruits and fermentating products (Schroder et al. 2014). $\beta$-Glucosidases can also be used to improve the organoleptic properties of citrus fruit juices, in which it reduced the bitterness that is due to a glucosidic compound, naringin (4,5,7-trihydroxyflavanone-7rhamnoglucoside) (Roitner et al. 1984; Keerti et al. 2014). After treatment of $\beta$-glucosidases, the reduction of fruit bitterness or gellan hydrolysis leads to the reduction in 
viscosity of fruit juice was also observed (Schroder et al. 2014). Recently, Keerti et al. (2014) have isolated and characterized a thermostable $\beta$-glucosidase from Bacillus subtilis and applied it to enhance the quality of sugarcane juice after immobilizing it into alginate beads.

\section{Other applications of $\beta$-glucosidase}

$\beta$-Glucosidases are used for the synthesis of oligosaccharides and alkyl-glycosides (Bankova et al. 2006). Oligosaccharides can be used as therapeutic agents, diagnostic tools and growth promoting agent. They have important functions in biological systems including fertilization, embryogenesis and cell proliferation. Alkyl-glycosides are nonionic surfactants with high biodegradability and also have antimicrobial properties. Hence, they have potential application in pharmaceutical, chemical, cosmetic, food and detergent industries as these can be hydrolyzed by $\beta$-glucosidase (Bankova et al. 2006). Enzymes from the source plants or other sources may be added to foods and beverages before, during, or after processing to enhance food quality. Thus, $\beta$-glucosidases with desirable properties may be focused for plant breeding programs, tissue culture and recombinant technologies to increase their overproduction in transgenic microbial or plant hosts and their catalytic properties for flavor enhancement and stability.

Aside from flavor enhancement, foods, feeds and beverages may be improved nutritionally by release of vitamins, antioxidants and other beneficial compounds from their glycosides. Opassiri et al. (2004) studied that vitamin $\mathrm{B}_{6}$ (pyridoxine) can be released from pyridoxine glucoside by $\beta$-glucosidase in rice. Other vitamins are also found as glucosides in different plants and release of their aglycones may improve their nutritional availability. This enzyme is also able to hydrolyze anthocyanins producing anthocyanidins and sugars. The resulting aglycones process little color and are less soluble than anthocyanins tend to precipitate and can be removed more easily. It is very much helpful in orange industry as it helps in color changing during pasteurization. $\beta$-Glucosidase supplementation was beneficial for single-stomached animals such as pigs and chickens in which cellulose degradation was enhanced by this enzyme leading to better nutrient utilization (Zhang et al. 1996).

As evident from previous sections, the wide functional implications and industrial applications of $\beta$-glucosidases make it a promising target for studies related to its higher production, novel enzyme, better stability, etc. Although $\beta$ glucosidases are having tremendous industrial demand but a suitable industrial $\beta$-glucosidase fulfilling all the desired properties is still lacking and studies are continued in anticipation of a novel enzyme with such properties.
In conclusion, an understanding of in vivo functional roles of these enzymes, biochemical properties, existing applications and well characterized heterogeneous expression technology discussed in this review will help in improvement of these enzymes using enzyme engineering and more relevant applications could be emerged in near future.

\section{Compliance with ethical standards}

Conflict of interest The authors declare that there is no conflict of interest in publication of this manuscript.

Open Access This article is distributed under the terms of the Creative Commons Attribution 4.0 International License (http:// creativecommons.org/licenses/by/4.0/), which permits unrestricted use, distribution, and reproduction in any medium, provided you give appropriate credit to the original author(s) and the source, provide a link to the Creative Commons license, and indicate if changes were made.

\section{References}

Aftab S, Aftab MN, Ikram-Ul-Haq MMJ, Zafar A, Iqbal I (2012) Cloning and expression of endo-1, $4-\beta$-glucanase gene from Bacillus licheniformis ATCC 14580 into Escherichia coli BL21 (DE 3). Afr J Biotechnol 11:2846-2854

Agrawal R, Satlewal A, Verma AK (2012) Development of a $\beta$ glucosidase hyperproducing mutant by combined chemical and UV mutagenesis. 3Biotech. doi:10.1007/s13205-012-0095-Z

Arribas JCD, Herrero AG, Martin-Lomas M, He S, Withers SG (2000) Differential mechanism-based labeling and unequivocal activity assignment of the two active sites of intestinal lactase/ phlorizin hydrolase. Eur J Biochem 267:6996-7005

Bai H, Wang H, Sun J, Irfan M, Han M, Huang Y, Han X, Yang Q (2013) Production, purification and characterization of novel beta-glucosidase from newly isolated Penicillium simplicissimum H-11 in submergence fermentation. EXCLI J 12:528-540

Bankova E, Bakalova N, Petrova S, Kolev D (2006) Enzymatic synthesis of oligosaccharides and alkylglycosides in waterorganic media via transglycosylation of lactose. Biotechnol Biotechnol Equip 20:114-119

Barleben L, Ma X, Koepke J, Peng G, Michel H, Stfckigt J (2005) Expression, purification, crystallization and preliminary X-ray analysis of strictosidine glucosidase, an enzyme initiating biosynthetic pathways to a unique diversity of indole alkaloid skeletons. Biochim Biophys Acta 1747:89-92

Barleben L, Panjikar S, Ruppert M, Koepke J, Stockigt J (2007) Molecular architecture of strictosidine glucosidase: the gateway to the biosynthesis of the monoterpenoid indole alkaloid family. Plant Cell 19:2886-2897

Bauer S, Vasu P, Persson S, Mort AJ, Somerville CR (2006) Development and application of a suite of polysaccharidedegrading enzymes for analyzing plant cell walls. Proc Natl Acad Sci 103:11417-11422

Berrin JG, McLauchlan WR, Needs P, Williamson G, Puigserver A, Kroon PA, Juge N (2002) Functional expression of human liver cytosolic $\beta$-glucosidase in Pichia pastoris: insights into its role in the metabolism of dietary glucosides. Eur $\mathrm{J}$ Biochem 269:249-258

Bhat M, Bhat S (1997) Cellulose degrading enzymes and their potential industrial applications. Biotechnol Adv 15:583-620 
Bhatia Y, Mishra S, Bisaria V (2002) Microbial $\beta$-glucosidases: cloning, properties, and applications. Crit Rev Biotechnol 22:375-407

Bujang NS, Harrison NA, Su NY (2014) Molecular cloning of five $\beta$ Glucosidases from four species of higher termites (Blattodea termitidae). Ann Entomol Soc Am 107(1):251-256

Butters TD (2007) Gaucher disease. Curr Opin Chem Biol 11:412-418

Byeon GM, Lee KS, Gui ZZ, Kim I, Kang PD, Lee SM, Sohn HD, Jin BR (2005) A digestive beta-glucosidase from the silkworm, Bombyx mori: cDNA cloning, expression and enzymatic characterization. Comp Biochem Physiol B Biochem Mol Biol 141(4):418-427

Cairns JRK, Esen A (2010) $\beta$-Glucosidase. Cell Mol Life Sci 67:3389-3405

Cantarel BL, Coutinho PM, Rancurel C, Bernard T, Lombard V, Henrissat B (2009) The Carbohydrate-Active EnZymes database (CAZy): an expert resource for glycogenomics. Nucleic Acids Res 37:D233-D238

Chan AKN, Wang YY, Ng K, Fu Z, Wong W (2011) Cloning and characterization of a novel cellobiase gene, cba3, encoding the first known $\beta$-glucosidase of glycoside hydrolase family 1 of Cellulomonas biazotea. Gene 493:52-61

Chang J, Park IH, Lee YS, Ahn SC, Zhou Y, Choi YL (2011) Cloning, expression, and characterization of $\beta$-glucosidase from Exiguobacterium sp. DAU5 and transglycosylation activity. Biotechnol Bioprocess Eng 16:97-106

Chauve M, Mathis H, Huc D, Casanave D, Monot F, Ferreira NL (2010) Comparative kinetic analysis of two fungal $\beta$-glucosidases. Biotechnol Biofuels 3:1-8

Chen M, Qin Y, Liu Z, Liu K, Wang F, Qu Y (2010a) Isolation and characterization of a $\beta$-glucosidase from Penicillium decumbens and improving hydrolysis of corncob residue by using it as cellulase supplementation. Enzyme Microbial Technol 46:444-449

Chen S, Hong Y, Shao Z, Liu Z (2010b) A cold-active $\beta$-Glucosidase (Bgl1C) from a sea bacteria Exiguobacterium oxidotolerans A011. World J Microbiol Biotechnol 26:1427-1435

Chen HL, Chen YC, Lu MYJ, Chang JJ, Wang HTC et al (2012) A highly efficient beta-glucosidase from a buffalo rumen fungus Neocallimastix patriciarum W5. Biotechnol Biofuels 5(24):1-10

Cherubini F (2010) The biorefinery concept: using biomass instead of oil for producing energy and chemicals. Energy Convers Manag 51:1412-1421

Cobucci-Ponzano B, Aurilia V, Riccio G et al (2010) A new archaeal $\beta$-Glycosidase from Sulfolobus solfataricus: seeding a novel retaining $\beta$-glycan-specific glycoside hydrolase family along with the human non-lysosomal glucosyl ceramidase GBA2. J Biol Chem 285(27):20691-20703

Collins CM, Murray PG, Denman S, Morrissey JP, Byrnes L, Teeri TT, Tuohy MG (2007) Molecular cloning and expression analysis of two distinct $\beta$-glucosidase genes, bg1 and aven 1 with very different biological roles from the thermophilic, saprophytic fungus Talaromyces emersonii. Mycol Res 111:840-849

Dashtban M, Qin W (2012) Overexpression of an exotic thermotolerant $\beta$-glucosidase in Trichoderma reesei and its significant increase in cellulolytic activity and saccharification of barley straw. Microb Cell Fact 11(63):1-15

Davies G, Henrissat B (1995) Structures and mechanisms of glycosyl hydrolases. Structure 3:853-859

Dharmawardhana DP, Ellis BE, Carlson JE (1999) cDNA cloning and heterologous expression of coniferin $\beta$-glucosidase. Plant Mol Biol 40:365-372

Doi RH, Kosugi A (2004) Cellulosomes: plant-cell-wall-degrading enzyme complexes. Nat Rev Microbiol 2:541-551
Escamilla-Trevino LL, Chen W, Card ML, Shih MC, Cheng CL, Poulton JE (2006) Arabidopsis thaliana beta-glucosidases BGLU45 and BGLU46 hydrolyse monolignol glucosides. Phytochemistry 67:1651-1660

Fan G, Xu Y, Zhang X, Lei S, Yang S, Pan S (2011a) Characteristics of immobilised $\beta$-glucosidase and its effect on bound volatile compounds in orange juice. Int $\mathrm{J}$ Food Sci Technol 46(11):2312-2320

Fan HX, Miao LL, Liu Y, Liu HC, Liu ZP (2011b) Gene cloning and characterization of a cold-adapted $\beta$-glucosidase belonging to glycosyl hydrolase family 1 from a psychrotolerant bacterium Micrococcus antarcticus. Enzyme Microbial Technol 49:94-99

Gilbert HJ, Stalbrand H, Brumer H (2008) How the walls come tumbling down: recent structural biochemistry of plant polysaccharide degradation. Curr Opin Plant Biol 11:338-348

Gonzalez-Pombo P, Farina L, Carrau F, Batista-Viera F, Brena BM (2011) A novel extracellular $\beta$-glucosidase from Issatchenkia terricola: isolation, immobilization and application for aroma enhancement of white Muscat wine. Process Biochem 46(1):385-389

Gu NY, Kim JL, Kim HJ, You DJ, Kim HW, Jeon SJ (2009) Gene cloning and enzymatic properties of hyperthermostable $\beta$-glycosidase from Thermus thermophilus HJ6. J Biosci Bioeng 107:21-26

Gueguen Y, Chemardin P, Janbon G, Arnaud A, Galzy P (1998) Investigation of the $\beta$-glucosidases potentialities of yeast strains and application to bound aromatic terpenols liberation. Stud Organic Chem 53:149-157

Gunata Z, Vallier M, Sapis J, Baumes R, Bayonove C (1994) Enzymatic synthesis of monoterpenyl $\beta$-D-glucosides by various $\beta$-glucosidases. Enzyme Microbial Technol 16:1055-1058

Ha SJ, Galazka JM, Kim SR, Choi JH, Yang X, Seo JH, Glass NL, Cate JHD, Jin YS (2011) Engineered Saccharomyces cerevisiae capable of simultaneous cellobiose and xylose fermentation. Proc Natl Acad Sci 108(2):2504-2509

Haerter AC, Voegele RT (2004) A novel $\beta$-glucosidase in Uromyces fabae: feast or fight? Curr Genet 45:96-103

Harhangi HR, Steenbakkers PJM, Akhmanova A, Jetten MSM, van der Drift C, Op den Camp HJM (2002) A highly expressed family $1 \beta$-glucosidase with transglycosylation capacity from the anaerobic fungus Piromyces sp. E2. Biochim Biophys Acta 1574:293-303

Harris PV, Welner D, McFarland KC, Re E, Poulsen JN, Brown K, Salbo R, Ding H, Vlasenko E, Merino S, Xu F, Cherry J, Larsen S, Leggio LL (2010) Stimulation of lignocellulosic biomass hydrolysis by proteins of glycoside hydrolase family 61: structure and function of a large, enigmatic family. Biochemistry 49(15):3305-3316

Hati S, Vij S, Singh BP, Mandal S (2015) $\beta$-Glucosidase activity and bioconversion of isoflavones during fermentation of soymilk. J Sci Food Agric 95:216-220

Hays WS, Wheeler DE, Eghtesad B, Glew RH, Johnston DE (1998) Expression of cytosolic beta-glucosidase in guinea pig liver cells. Hepatology 28(1):156-163

Henrissat B, Davies G (1997) Structural and sequence-based classification of glycoside hydrolases. Curr Opin Struct Biol 7:637-644

Hong J, Tamaki H, Kumagai $\mathrm{H}$ (2007) Cloning and functional expression of thermostable $\beta$-glucosidase gene from Thermoascus aurantiacus. Appl Microbiol Biotechnol 73:1331-1339

Isorna P, Polaina J, Garcia LL, Canada FJ, Gonzalez B, Aparicio JS (2007) Crystal structures of Paenibacillus polymyxa $\beta$-Glucosidase B complexes reveal the molecular basis of substrate specificity and give new insights into the catalytic machinery of family I glycosidases. J Mol Biol 371:1204-1218 
Issam SM, Mohamed G, Dominique LM, Thierry M, Farid L, Nejib M (2004) A $\beta$-glucosidase from Sclerotinia sclerotiorum. Appl Biochem Biotechnol 112:63-77

Izumi T, Piskula MK, Osawa S, Obata A, Tobe K, Saito M, Kataoka S, Kubota Y, Kikuchi M (2000) Soy isoflavone aglycones are absorbed faster and in higher amounts than their glucosides in humans. J Nutr 130:1695-1699

Jabbour D, Klippel B, Antranikian G (2012) A novel thermostable and glucose-tolerant $\beta$-glucosidase from Fervidobacterium islandicum. Appl Microbiol Biotechnol 93:1947-1956

Jeon E, Hyeon JE, Eun LS, Park BS, Kim SW, Lee J, Han SO (2009a) Cellulosic alcoholic fermentation using recombinant Saccharomyces cerevisiae engineered for the production of Clostridium cellulovorans endoglucanase and Saccharomycopsis fibuligera $\beta$-glucosidase. FEMS Microbiol Lett 301:130-136

Jeon E, Hyeon JE, Suh DJ, Suh YW, Kim SW, Song KH, Han SO (2009b) Production of cellulosic ethanol in Saccharomyces cerevisiae heterologous expressing Clostridium thermocellum endoglucanase and Saccharomycopsis fibuligera $\beta$-glucosidase Genes. Mol Cells 28:369-373

Jones P, Vogt T (2001) Glycosyltransferases in secondary plant metabolism: tranquilizers and stimulant controllers. Planta 213:164-174

Jones PR, Andersen MD, Nielsen JS, Hoj PB, Moller BL (2000) The biosynthesis, degradation, transport and possible function of cyanogenic glucosides. In: Romeo JT, Ibrahim R, Varin L, De Luca V (eds) Evolution of metabolic pathways. Elsevier Science Ltd., New York, pp 191-247

Kang SK, Cho KK, Ahn JK, Kang SH, Lee SH, Lee HG, Choi YJ (2005) Cloning, expression, and enzyme characterization of thermostable $\beta$-glycosidase from Thermus flavus AT-62. Enzyme Microbial Technol 37:655-662

Keerti, Gupta A, Kumar V, Dubey A, Verma AK (2014) Kinetic characterization and effect of immobilized thermostable $\beta$ glucosidase in alginate gel Beads on sugarcane juice. ISRN biochemistry volume 2014, Article ID 178498

Kempton JB, Withers SG (1992) Mechanism of Agrobacterium $\beta$ glucosidase: kinetic studies. Biochemistry 31:9961-9969

Kim S, Baek SH, Lee K, Hahn JS (2013) Cellulosic ethanol production using a yeast consortium displaying a minicellulosome and $\beta$-glucosidase. Microb Cell Fact 12(14):1-7

Kitagawa T, Tokuhiro K, Sugiyama H, Kohda K, Isono N, Hisamatsu M, Takahashi $\mathrm{H}$, Imaeda $\mathrm{T}$ (2010) Construction of a $\beta$ glucosidase expression system using the multistress-tolerant yeast Issatchenkia orientalis. Appl Microbiol Biotechnol 87:1841-1853

Knudsen C (2014) The evolution of plant chemical defence- new roles for hydroxynitrile glucosides in Lotus japonicus. Department of Plant and Environmental Sciences, Faculty of Science, University of Copenhagen

Koffi YG, Konan HK, Kouadio JPEN, Dabonne S, Due EA, Kouame LP (2012) Purification and biochemical characterization of betaglucosidase from cockroach, Periplaneta americana. J Anim Plant Sci 13:1747-1757

Kotaka A, Bando H, Kaya M, Kato-Murai M, Kuroda K, Sahara H, Hata Y, Kondo A, Ueda M (2008) Dirtct ethanol production from barley $\beta$-glucan by sake yeast Aspergillus oryzae $\beta$ glucosidase and endoglucanase. J Biosci Bioeng 105(6):622-627

Krisch J, Tako M, Papp T, Vagvolgyi C (2010) Characteristics and potential use of $\beta$-glucosidases from Zygomycetes. In: MendezVilas A (ed) Current Research, Technology and Education, Topics in Applied Microbiology and Microbial Biotechnology, pp 891-896

Kuntothom T, Luang S, Harvey AJ, Fincher GB, Opassiri R, Hrmova M, Cairns KJR (2009) Rice family GH1 glycoside hydrolases with $\beta$-D-glucosidase and $\beta$-D-mannosidase activities. Arch Biochem Biophys 491:85-95
Kuo LC, Lee KT (2007) Cloning, expression, and characterization of two $\beta$-glucosidases from isoflavone glycoside-hydrolyzing Bacillus subtilis natto. J Agric Food Chem 56:119-125

Leah R, Kigel J, Svendsen I, Mundy J (1995) Biochemical and molecular characterization of a barley seed $\beta$-glucosidase. J Biol Chem 270:15789-15797

Lee KH, Piao HL, Kim HY, Choi SM, Jiang F, Hartung W, Hwang I, Kwak JM, Lee IJ, Hwang I (2006) Activation of glucosidase via stress-induced polymerization rapidly increases active pools of abscisic acid. Cell 126:1109-1120

Lee SM, Jin LH, Kim JH, Han SO, Na HB, Hyeon T, Koo YM, Kim J, Lee JH (2010) $\beta$-Glucosidase coating on polymer nanofibers for improved cellulosic ethanol production. Bioprocess Biosyst Eng 33:141-147

Levis S, Strickman-Stein N, Doerge DR, Krischer J (2010) Design and baseline characteristics of the soy phytoestrogens as replacement estrogen (SPARE) study- a clinical trial of the effects of soy isoflavones in menopausal women. Contemp Clin Trials 31:293-302

Li D, Li X, Dang W, Tran PL, Park S, Oh B, Hong W, Lee J, Park K (2013) Characterization and application of an acidophilic and thermostable $\beta$-glucosidase from Thermofilum pendens. J Biosci Bioeng 115(5):490-496

Li Y, Liu N, Yang H, Zhao F, Yu Y, Tian Y, Lu X (2014) Cloning and characterization of a new $\beta$-Glucosidase from a metagenomic library of Rumen of cattle feeding with Miscanthus sinensis. BMC Biotechnol 14:85-94

Liggins J, Bluck LJC, Runswick S, Atkinson C, Coward WA, Bingham SA (2000) Daidzein and genistein contents of vegetables. Br J Nutr 84:717-725

Litzinger S, Fischer S, Polzer P, Diederichs K, Welte W, Mayer C (2010) Structural and kinetic analysis of Bacillus subtilis $N$ acetylglucosaminidase reveals a unique Asp-His dyad mechanism. J Biol Chem 285(46):35675-35684

Liu Z, Kanjo Y, Mizutani S (2010) A review of phytoestrogens: their occurrence and fate in the environment. Water Res 44:567-577

Liu J, Zhang X, Fang Z, Fang W, Peng H, Xiao Y (2011) The 184th residue of $\beta$-glucosidase Bgl1B plays an important role in glucose tolerance. J Biosci Bioeng 112(5):447-450

Liu D, Zhang R, Yang X, Zhang Z, Song S, Miao Y, Shen Q (2012a) Characterization of a thermostable beta-glucosidase from Aspergillus fumigatus $\mathrm{Z5}$, and its functional expression in Pichia pastoris X33. Microb Cell Fact 11:25-29

Liu ZL, Weber SA, Cotta MA, Li SZ (2012b) A new $\beta$-glucosidase producing yeast for lower-cost cellulosic ethanol production from xylose-extracted corncob residues by simultaneous saccharification and fermentation. Bioresour Technol 104:410-416

Lynd LR, Weimer PJ, Van Zyl WH, Pretorius IS (2002) Microbial cellulose utilization: fundamentals and biotechnology. Microbiol Mol Biol Rev 66:506-577

Ma L, Zhang J, Zou G, Wang C, Zhou Z (2011) Improvement of cellulase activity in Trichoderma reesei by heterologous expression of a beta-glucosidase gene from Penicillium decumbens. Enzyme Microbial Technol 49:366-371

Marana SR, Jacobs-Lorena M, Terra WR, Ferreira C (2001) Amino acid residues involved in substrate binding and catalysis in an insect digestive $\beta$-glycosidase. Biochim Biophys Acta 1545:41-52

Marazza JA, Garro MS, Savoy de Giori G (2009) Aglycone production by Lactobacillus rhamnosus CRL981 during soymilk fermentation. Food Microbiol 26:333-339

Matteotti C, Thonart P, Francis F, Haubruge E, Destain J, Brasseur C, Bauwens J, Pauw ED, Portetelle D, Vandenbol M (2011) New glucosidase activities identified by functional screening of a genomic DNA library from the gut microbiota of the termite Reticulitermes santonensis. Microbiol Res 166(8):629-642 
Mfombep PM, Senwo ZN, Isikhuemhen OS (2013) Enzymatic activities and kinetic properties of $\beta$-glucosidase from selected white rot fungi. Adv Biol Chem 3:198-207

Morant AV, Jorgensen K, Jorgensen C, Paquette SM, Sanchez-Perez R, Moller BL, Bak S (2008) $\beta$-Glucosidases as detonators of plant chemical defense. Phytochemistry 69:1795-1813

Murray P, Aro N, Collins C, Grassick A, Penttila M, Saloheimo M, Tuohy M (2004) Expression in Trichoderma reesei and characterization of a thermostable family $3 \beta$-glucosidase from the moderately thermophilic fungus Talaromyces emersonii. Protein Expr Purif 38:248-257

Nijikken Y, Tsukada T, Igarashi K, Samejima M, Wakagi T, Shoun H, Fushinobu S (2007) Crystal structure of intracellular family 1 $\beta$-glucosidase BGL1A from the basidiomycete Phanerochaete chrysosporium. FEBS Lett 581:1514-1520

Nomura T, Quesada AL, Kutchan TM (2008) The new $\beta$-Dglucosidase in terpenoid-isoquinoline alkaloid biosynthesis in Psychotria ipecacuanha. J Biol Chem 283:34650-34659

Opassiri R, Hua Y, Wara-Aswapati O, Akiyama T, Svasti J, Esen A, Cairns JRK (2004) Beta-glucosidase, exo-beta-glucanase and pyridoxine transglucosylase activities of rice BGlu1. Biochem $\mathrm{J}$ 379:125-131

Pandey M, Mishra S (1997) Expression and characterization of Pichia etchellsii $\beta$-glucosidase in Escherichia coli. Gene 190:45-51

Park JK, Wang LX, Patel HV, Roseman S (2002) Molecular cloning and characterization of a unique $\beta$-glucosidase from Vibrio cholerae. J Biol Chem 277:29555-29560

Park NY, Cha J, Kim DO, Park CS (2007) Enzymatic characterization and substrate specificity of thermostable $\beta$-glycosidase from hyperthermophilic archaea, Sulfolobus shibatae, expressed in E. coli. J Microbiol Biotechnol 17:454-460

Qi M, Jun HS, Forsberg CW (2008) Cel9D, an atypical 1, 4- $\beta$-Dglucan glucohydrolase from Fibrobacter succinogenes: characteristics, catalytic residues, and synergistic interactions with other cellulases. J Bacteriol 190:1976-1984

Rajan SS, Yang X, Collart F, Yip VL, Withers SG, Varrot A, Thompson J, Davies GJ, Anderson WF (2004) Novel catalytic mechanism of glycoside hydrolysis based on the structure of an $\mathrm{NAD}^{+} / \mathrm{Mn}^{2+}$-dependent phospho-alpha-glucosidase from Bacillus subtilis. Structure 12:1619-1629

Ramachandrana P, Tiwari MK, Singh RK, Haw J, Jeya M, Lee J (2012) Cloning and characterization of a putative $\beta$-glucosidase (NfBGL595) from Neosartorya fischeri. Process Biochem 47:99-105

Rimbach G, Boesch CS, Frank J, Fuchs D, Wenzel U, Daniel H, Hall WL, Weinberg PD (2008) Dietary isoflavones in the prevention of cardiovascular disease-a molecular perspective. Food Chem Toxicol 46:1308-1319

Riou C, Salmon JM, Vallier MJ, Gunata Z, Barre P (1998) Purification, characterization, and substrate specificity of a novel highly glucose-tolerant $\beta$-glucosidase from Aspergillus oryzae. Appl Environ Microbiol 64:3607-3614

Riseh NS, Ghadamyari M, Motamediniya B (2012) Biochemical characterisation of $\alpha$ - and $\beta$-Glucosidases and $\alpha$ - and $\beta$ galactosidases from red palm weevil, Rhynchophorus ferrug ineus (Olivier) (Col.: Curculionide). Plant Prot Sci 48(2):85-93

Roitner M, Schalkhammer T, Pittner F (1984) Characterization of naringinase from Aspergillus niger. Monatshefte fur Chemie/ Chem Mon 115:1255-1267

Roy P, Mishra S, Chaudhary TK (2005) Cloning, sequence analysis, and characterization of a novel $\beta$-glucosidase-like activity from Pichia etchellsii. Biochem Biophys Res Commun 336:299-308

Schroder C, Elleuche S, Blank S, Antranikian G (2014) Characterization of a heat-active archaeal $\beta$-glucosidase from a hydrothermal spring metagenome. Enzyme Microbial Technol 57:48-54
Sestelo ABF, Poza M, Villa TG (2004) $\beta$-Glucosidase activity in a Lactobacillus plantarum wine strain. World J Microbiol Biotechnol 20:633-637

Sherameti I, Venus Y, Drzewiecki C, Tripathi S, Dan VM, Nitz I, Varma A, Grundler FM, Oelmuller R (2008) PYK10, a $\beta$ glucosidase located in the endoplasmatic reticulum, is crucial for the beneficial interaction between Arabidopsis thaliana and the endophytic fungus Piriformospora indica. Plant J 54:428-439

Singh RK, Zhang YW, Nguyen NPT, Jeya M, Lee JK (2011) Covalent immobilization of $\beta$-1,4-glucosidase from Agaricus arvensis onto functionalized silicon oxide nanoparticles. Appl Microbiol Biotechnol 89:337-344

Skory CD, Freer SN (1995) Cloning and characterization of a gene encoding a cell-bound, extracellular beta-glucosidase in the yeast Candida wickerhamii. Appl Environ Microbiol 61:518-525

Sorensen A, Lubeck M, Lubeck PS, Ahring BK (2013) Fungal betaglucosidases: a bottleneck in industrial use of lignocellulosic materials. Biomolecules 3:612-631

Street IP, Kempton JB, Withers SG (1992) Inactivation of a $\beta$ glucosidase through the accumulation of a stable 2-deoxy-2fluoro-alpha-D-glucopyranosyl-enzyme intermediate: a detailed investigation. Biochemistry 31:9970-9978

Su E, Xia T, Gao L, Dai Q, Zhang Z (2010) Immobilization of $\beta$ glucosidase and its aroma-increasing effect on tea beverage. Food Bioprod Process 88(2):83-89

Suzuki H, Takahashi S, Watanabe R, Fukushima Y, Fujita N, Noguchi A, Yokoyama R, Nishitani K, Nishino T, Nakayama T (2006) An isoflavone conjugate-hydrolyzing $\beta$-Glucosidase from the roots of soybean (Glycine max) seedlings: purification, gene cloning, phylogenetics and cellular localization. J Biol Chem 281(40):30251-30259

Tajima K, Nakajima K, Yamashita H, Shiba T, Munekata M, Takai M (2001) Cloning and sequencing of the beta-glucosidase gene from Acetobacter xylinum ATCC 23769. DNA Res 8:263-269

Takagi Y, Kriehuber E, Imokawa G, Elias PM, Holleran WM (1999) $\beta$-Gluco-cerebrosidase activity in mammalian stratum corneum. J Lipid Res 40(5):861-869

Tang H, Hou J, Shen Y, Xu L, Yang H, Fang X, Bao X (2013) High $\beta$-glucosidase secretion in Saccharomyces cerevisiae improves the efficiency of cellulase hydrolysis and ethanol production in simultaneous saccharification and fermentation. J Microbiol Biotechnol 23(11):1577-1585

Teeri TT (1997) Crystalline cellulose degradation: new insight into the function of cellobiohydrolases. Trends Biotechnol 15:160-167

Teugjas H, Valjamae P (2013) Selecting $\beta$-glucosidases to support cellulases in cellulose saccharification. Biotechnol Biofuels $6(105): 1-13$

Tolonen AC, Haas W, Chilaka AC, Aach J, Gygi SP, Church G (2011) Proteome-wide systems analysis of a cellulosic biofuelproducing microbe. Mol Syst Biol 7(461):1-12

Tribolo S, Berrin JG, Kroon PA, Czjzek M, Juge N (2007) The crystal structure of human cytosolic $\beta$-glucosidase unravels the substrate aglycone specificity of a family 1 glycoside hydrolase. J Mol Biol 370:964-975

Turner BL, Hopkins DW, Haygarth PM, Ostle N (2002) $\beta$-Glucosidase activity in pasture soils. Appl Soil Ecol 20:157-162

Umezurike GM (1976) The $\beta$-Glucosidase in the gut contents of the snail Achatina achatina: energy-dependent modification of structure and activity. Biochem J 157:381-387

Verdoucq L, Moriniere J, Bevan DR, Esen A, Vasella A, Henrissat B, Czjze M (2004) Structural determinants of substrate specificity in family $1 \beta$-glucosidases. J Biol Chem 279:31796-31803

Verma OP, Singh A, Singh N, Chaudhary O (2011) Isolation, purification and characterization of $\beta$-glucosidase from Rauvolfia serpentine. J Chem Eng Process Technol 2(5):1-4 
Verma AK, Saini S, Nishad S, Kumar V, Dubey A (2013) Production, purification and characterization of $\beta$-glucosidase from Bacillus subtilis strain PS isolated from sugarcane bagasse. J Pure Appl Microbiol 7(1):803-810

Wang Q, Trimbur D, Graham R, Warren RAJ, Withers SG (1995) Identification of the acid/base catalyst in Agrobacterium faecalis $\beta$-glucosidase by kinetic analysis of mutants. Biochemistry 34:14554-14562

Wang L, Liu QM, Sung BH, An DS, Lee HG, Kim SG, Kim SC, Lee ST, Im WT (2011) Bioconversion of ginsenosides Rb1, Rb2, Rc and Rd by novel $\beta$-glucosidase hydrolyzing outer 3-O glycoside from Sphingomonas sp. 2F2: cloning, expression, and enzyme characterization. J Biotechnol 156:125-133

Warzecha H, Gerasimenko I, Kutchan TM, Stockigt J (2000) Molecular cloning and functional bacterial expression of a plant glucosidase specifically involved in alkaloid biosynthesis. Phytochemistry 54:657-666

Withers SG, Street IP, Bird P, Dolphin DH (1987) 2-Deoxy-2fluoroglucosides: a novel class of mechanism-based glucosidase inhibitors. J Am Chem Soc 109:7530-7531

Withers SG, Warren RAJ, Street IP, Rupitz K, Kempton JB, Aebersold R (1990) Unequivocal demonstration of the involvement of a glutamate residue as a nucleophile in the mechanism of a retaining glycosidase. J Am Chem Soc 112:5887-5889

Withers SG, Rupitz K, Trimbur D, Warren RAJ (1992) Mechanistic consequences of mutation of the active site nucleophile Glu 358 in Agrobacterium $\beta$-glucosidase. Biochemistry 31:9979-9985

Wu Y, Chi S, Yun C, Shen Y, Tokuda G, Ni J (2012) Molecular cloning and characterization of an endogenous digestive $\beta$ glucosidase from the midgut of the fungus-growing termite Macrotermes barneyi. Insect Mol Biol 21(6):604-614
Xue YP, Jin LQ, Liu ZQ, Zhang JF, Zheng YG (2008) Purification and characterization of $\beta$-glucosidase from Reticulitermes flaviceps and its inhibition by valienamine and validamine. Afr $\mathbf{J}$ Biotechnol 7(24):4595-4601

Yanase H, Nozaki K, Okamoto K (2005) Ethanol production from cellulosic materials by genetically engineered Zymomonas mobilis. Biotechnol Lett 27:259-263

Yapi D, Yapi A, Gnakri D, Niamke SL, Kouame LP (2009) Purification and biochemical characterization of a specific $\beta$ glucosidase from the digestive fluid of larvae of the palm weevil, Rhynchophorus palmarum. J Insect Sci 9(4):1-13

Zagrobelny M, Bak S, Rasmussen AV, Jorgensen B, Naumann CM, Moller BL (2004) Cyanogenic glucosides and plant-insect interactions. Phytochemistry 65:293-306

Zagrobelny M, Bak S, Møller BL (2008) Cyanogenesis in plants and arthropods. Phytochemistry 69:1457-1468

Zahoor S, Javed MM, Aftab MN (2011) Cloning and expression of $\beta$ glucosidase gene from Bacillus licheniformis into E. coli BL 21 (DE3). Biologia 66:213-220

Zhang Z, Marquardt RR, Wang G, Guenter W, Crow GH, Han Z, Bedford MR (1996) A simple model for predicting the response of chicks to dietary enzyme supplementation. J Anim Sci 74:394-402

Zhang D, Allen AB, Lax AR (2012) Functional analyses of the digestive $\beta$-glucosidase of formosan subterranean termites (Coptotermes formosanus). J Insect Physiol 58:205-210

Zhenming C, Zhe C, Guanglei L, Fang W, Liang J, Tong Z (2009) Saccharomycopsis fibuligera and its applications in biotechnology. Biotechnol Adv 27:423-431 